\title{
Environmental effects and initiatives of nuclear power via international initiatives in 1980s as a bipolar international policy
}

\author{
Çora Hakan ${ }^{1, *}$ \\ ${ }^{1}$ Istanbul Okan University, Istanbul, Turkey
}

\begin{abstract}
In 1980 American Nuclear Society scholars Walter Jordan and Samuel Glasstone delivered a coherent and methodological presentation of the consequences of nuclear power on the environment. Focusing on a multitude of matters extending from nuclear power and reactor safety to the discarding of waste heat and the biological outcomes of radiation, enclosed many of the concerns involving to nuclear environmental effect. Furthermore, America's diverse legacy has allowed competing claimants to propose conflicting opinions of its position in the conclusion of the Cold War and the reduction of nuclear conflicts in the 1990s. Particular specifics, nevertheless, are beyond argument. United States headed over a immense nuclear accumulation and sprung an costly struggle to construct a defense versus strategic missiles that aggravated frictions with Soviet Union. This paper is aimed for specialists in any specific area and they will find the study presented as of a specific time period in nature and is therefore studies of later periods is recommended for advanced studies. Nevertheless, the educated scholars will possibly find the study informative and illuminating, and the paper will serve well the commitment to educating of misinformed community too. This study is thus endorsed for use in any activities engaged at public education in its subject matter.
\end{abstract}

\section{Introduction}

As stated in the abstract the multitude of matters extending from nuclear power and reactor safety to the discarding of waste heat and the biological outcomes of radiation, enclosed many of the concerns involving to nuclear environmental effect[1]. Reagan's presidency covered one of the most turbulent periods in U.S.-Soviet affairs and the chronicle of the nuclear arms race [2]. Therefore, in this paper we will concentrate on Ronald Reagan who became a president as a long-time criticizer of detente and arms control with the Soviet Union, the foremost U.S. strategic rival throughout his existence in oval office. Reagan speeded strategic nuclear modernization strategies and propelled modern exertions to form a nationalized missile defense system via a Strategic Defense Initiative (SDI), fostering conflicts with the Soviet Union and provoking extensive public distress on the probability of war amid globe's two foremost nuclear superpowers.

Reagan and his counterparty Gorbachev ultimately settled the milestone Intermediate-

\footnotetext{
*Corresponding author: corahakan@gmail.com
} 
Range Nuclear Forces (INF) treaty and founded the basis for the Strategic Arms Reduction Treaty (START), that was completed in 1991. Nonetheless, the complete assurance of Reagan's and Gorbachev's propositions for far-reaching nuclear weapon reductions stay unsatisfied. American and Russian nuclear strengths, though reduced, still mutually challenge, and various strategic weapons systems fostered by Reagan endure or have been restored [3].

\section{Background and establishment SDI}

Ronald Reagan, who left his mark in the 1980s, was the first president to openly express his goal of ending the Cold War through the strategies he pursued during his presidency and to take steps in this direction. He focused on the development of defense systems for the security of the USA, even for the security of the free world. By 1981, the Soviets had many enemies. In Czechoslovakia, the movement launched by playwright Vaclav Havel, Charter 77, began to pressure Soviet leaders to declare their commitment to Helsinki human rights. The Papal conclave in the Vatican elected a Polish Pope, which surprised the whole world, especially the Kremlin. It was quite obvious that the new Pope would be fighting Moscow on matters related to Eastern Europe [2].

In Britain, Margaret Thatcher became prime minister by attacking planned economies. Lech Walesa, a very persistent shipyard worker in Poland, forced the government in Warsaw to recognize the only independent trade association within the Soviet Block. Finally, in the United States, Ronald Reagan became president, without allowing Carter to be re-elected and with an open promise to end the softening period. This outlook was proof that Moscow's strategies were wrong. While the number of enemies should have decreased in this process, a continuous increase was observed. During the Cold War, the situation of tying and not being able to defeat has revealed that bipolarity is not very reasonable in terms of organizing the world [2].

We can say that the softening period never meant an end to the war, it only made this process more reliable and more predictable. This could be considered a progress, but still many countries in many parts of the world were under the pressure of states they did not want. The gravediggers of Softening - Havel, Thatcher, Reagan, John Paul II, Walesa - were determined to change that. They did not have a common strategy, but one common goal: to end the Cold War. For Reagan, softening was a dream based on the belief that the Soviets would change their personality. Accordingly, Reagan started researching for the Strategic Defense Initiative (SDI) as soon as he got to work. His aim was to develop a system that could eliminate the effects of nuclear weapons and missiles and render them obsolete. It is thought to be a defense program and not intended to attack and was known to the American public as well to be that way. But the Soviets did not agree. They believed that this was not just a defensive attempt, its main purpose was to camouflage the attack, and in fact the war between them was carried into space. That's why they called this program "Star Wars" [3].

According to official definitions, SDI envisaged a "layered" defense aimed at destroying the approaching missile at each stage of the ballistic trajectory using a different technology. The functioning of the SDI meant that the fear and threat created by the Soviets that trusted their intercontinental ballistic missiles, had disappeared and the United States took a step forward. In fact, Reagan wanted to win this race rather than take a step forward. Its main purpose was not to "freeze" nuclear weapons, but to make them "ineffective and useless". In addition, Reagan was the first president ever to want the complete elimination of Nuclear Weapons amongst any US presidents [4].

The Strategic Defense Initiative (SDI) officially started with President Reagan's speech on 23 March 1983. According to many experts, the possible advantages and disadvantages of SDI were stated as follows [2]; 
* Eliminating the attacks that may occur with the change of the strategic nuclear balance before reaching the target,

* Billions of dollars in long-term savings in defense spending in order to stand against the Soviets,

* Soviets' superiority in ICBMs became meaningless,

* Forcing the Soviets, who lacked the power to participate in the space race and such a defense initiative, to take a step back,

* Innovations in many technological areas within the defense system,

* The fact that strategic and nuclear weapons could be stopped and destroyed would diminish the fear created by the nuclear power-based terror balance in the world and provide a fearless world environment.

Thirty years of nuclear armament continued at full speed, but defense initiatives were pushed to the background, perhaps because of the belief that it was not possible. However, the SDI was proof that there was a change in this sense for the United States under Reagan's presidency. Reagan's initiated SDI served exactly this purpose[3].

In Time's news on the 11th of March in 1985; SDI experts were allegedly planning to deploy a "satellite network" of hundreds of satellites containing weapons, detection and recognition devices to detect and then destroy missiles to be launched from the Soviets. In June 1986, when Ronald Reagan spoke about the Strategic Defense Initiative, he said [2]:

"Just as the roofs of our houses protect our family from rain, the shield to be created with SDI will protect us from nuclear missiles." This was the result of the belief that shields installed in space could detect and destroy enemy ballistic missiles as soon as they are launched. When this plan was realized, the anti-ballistic missile agreement between the USA and the Soviets would have lost its importance.

Those who opposed the SDI system argued that it was not possible to protect the USA with this system. With this system alone, it seemed impossible to stop the Soviets who had thousands of nuclear warheads like the atomic bombs that destroyed Hiroshima and Nagasaki. According to dissidents, while even an atomic bomb was enough to destroy a city, it was impossible to destroy thousands of them at the launch stage by following them with satellites placed in space. If the Soviets decided to attack, they could launch hundreds of missiles at the same time, neutralizing the sensor sensors of the US defense system. According to Gaddis, the SDI was for Reagan not only a bargaining element for the future, but an initiative to which he was firmly committed. However, this was a bluff that the USA could not realize in a short time, not even in years. But Reagan's persuasive speeches fueled the increasing fears of Soviet leaders to believe that it was going to happen immediately. On the Soviet front, this initiative was perceived as a technological achievement, a skill they could not cope with, rather than a pipe dream [5].

\section{Nonproliferation under Reagan and strategic control}

In the middle of $1982 \mathrm{~s}$, US government settled to recommence strategic nuclear arms reduction discussions, named START. The preliminary START proposition by America needed significantly vaster reductions in Soviets than in America and allies, particularly landestablished rockets that included the majority of the Soviet Union's strategic nuclear resources. The proposition further overlooked restraints in parts that the America was leading, like air-launched cruise missiles and strategic bomber aircrafts. USSR overruled the American methodology and suggested additional decreases in the SALT II structure. 24 months of unproductive dialogues continued. Later, in 1983, as America initiated placement of ground-launched cruise missiles and Pershing in its allied countries, the Soviets departed from the negotiating process [2]. 
In accordance with the views of scholars of this period, Reagan turn out to be gradually bothered concerning the likelihood of an unintentional nuclear exchange following America's nuclear war planning maneuvers in 1983-84 that steered the Soviet Union to transformation their level of nuclear alert. Said occurrence distressed Reagan, and January 1984 he stated that the uppermost urgency in America-Soviet affairs ought to be decreasing the jeopardy of nuclear war and lessening nuclear resources [4].

In a communication performed during the UN meeting only 6 weeks prior to 1984 presidential voting, Reagan situated him as a negotiator for peace by requesting a novel tour of wide-ranging arms dialogues with the Soviet Union. As the dialogues for arms blocked and community and congress backing for a nuclear arms restriction accumulating, Reagan introduced a fresh episode in the strategic discussion in 1983, by declaring his intention to acquire space-constructed anti-ballistic missile systems, which would result in making nuclear arms "obsolete and impotent." The presidency would consequently name the broad study works SDI, however this was rapidly relabeled "Star Wars" since of the systems' calculated dependence on high-technology beam and laser arms positioned in cosmos. Later on, Reagan presidency administrators have stated that the real methodological achievement of such a technique was insignificant; what actually counted was persuasion of the Soviet Union that they had to create unmaintainable high-tech and monetary obligations to retain speed with America. The Kremlin administration could thus be further cooperative to weapons control deals [3].

The Reagan presidency's works to avoid the extent of nuclear arms to other countries were normally minor to refuting the Kremlin's risk. Though his management guided the path in producing a missile export regulator institute, "the Missile Technology Control Regime", struggles intended at restraining Pakistan's developing nuclear arms agenda shown be slight and ineffective [2].

Pakistan was capable to weight its up keeping position for anti-Soviet insurgents in Afghanistan into a sacrifice of fines and a funding as American military aid. Instead of the penalties, the Reagan presidency pursued reassurances from military authorities of Pakistan that they would not enhance uranium for developing nuclear arms. Nevertheless, Pakistan had developed sufficient enriched uranium for one or two nuclear weapons in 1985. By the 1990s, prominent Pakistani atomic researchers had established a black-market nuclear dealing grid [3].

In January of 1985, when America installed new missile systems in European mainland, the Soviets settled with Reagan's proposition for recommencing weapons control dialogues on intermediate, defensive and strategic arms [4]. 


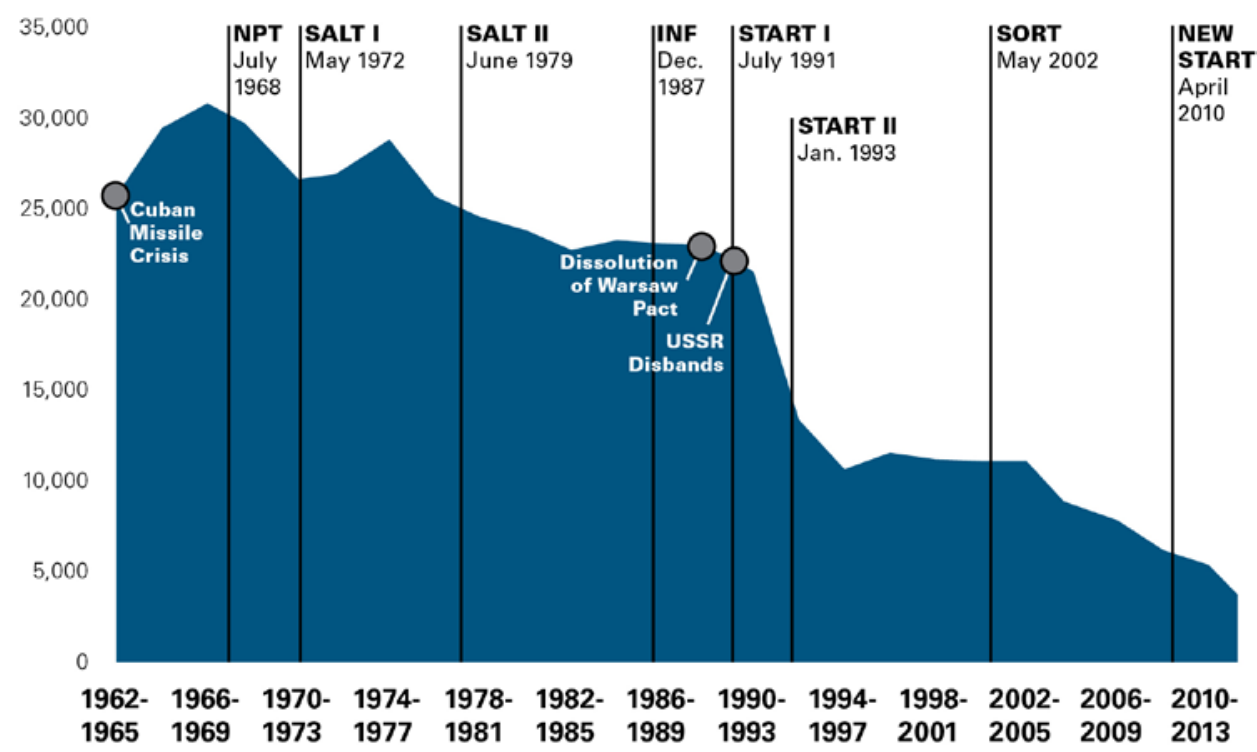

Fig. 1. Status of Nuclear Global Stockpiles (Source: US Department of Defense, Arms Control Association).

In July of 1985, Soviet leader Gorbachev announced the principal of numerous one-sided cessations on Soviet Union's atomic testing. Notwithstanding with congressional decrees insisting the initiations of dialogues on a all-inclusive test ban accord, Reagan did not take the same action with the Soviets, trusting that sustained testing was vital to SDI and nuclear modernization struggles. As an outcome, inclusive test ban meetings were deferred for additional 9 years. In January of 1986, Gorbachev responded United States' Star Wars initiative with a plan for nuclear disarmament with 3 parts that would conclude in 2000. While his government homogeneously overruled the proposition, Reagan's personal reply to his State Secretary, George Schultz, was, "Why wait until the end of the century for a world free of nuclear weapons?" [5]

Predictions for weapons control had a considerable obstruction when several intelligences reported Soviet Union's violations of the treaty. Reagan relinquished his preceding "political commitment" to SALT I and II regarding strategic offensive weapons, that led to a solid adverse reaction from American Congress and allied European countries and, paradoxically, he continued the weight for restrictions on the atomic accumulation [4].

\section{Reaction to strategic defense initiative}

Soviets' reaction to the Strategic Defense Initiative was harsh. Because they also knew very well that to dominate the space meant to dominate the world. During the Cold War, the weapons that the Soviet Union produced by devoting a large part of its economy to the military would be wasted with this attempt. The strategy of gaining advantage with the "first strike" attack, which the Soviet Union relied on so much, would not make sense either and if the USA succeeds in creating a missile-proof "shield", it would be inevitable that the USA will come to the forefront technologically in a period when the Soviets are economically troubled [2]. 


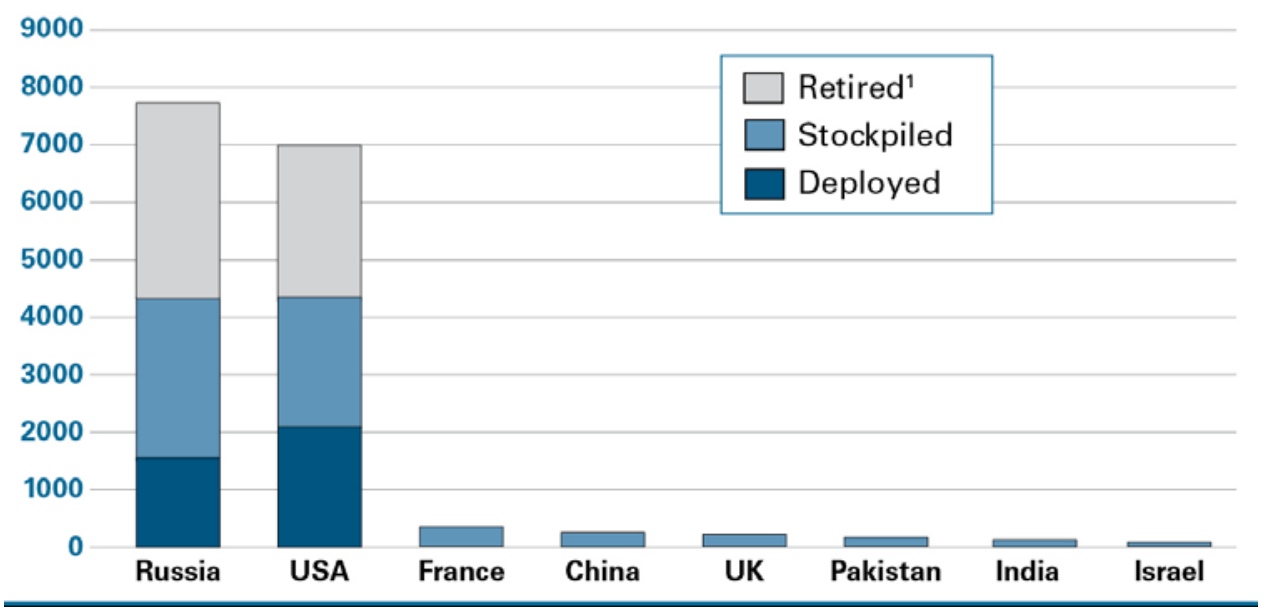

Fig. 2. Estimated Global Nuclear Inventories (Source: H. M. Kristensen \& R. S. Norris, 2014).

But according to Hook and Spanier, SDI would lead a new arms race that only attacked and defended. This would still be an economic burden and would only save a temporary period. Still, the Soviet Union lacked the power to enter such a race economically. Therefore, the SDI was extremely worrying for the Kremlin and caused the Soviets to lean towards new negotiations on arms limitations. In the 1984 elections, Reagan claimed the control of arms, which he had previously mocked. He defended the necessity of destroying nuclear weapons at the Genoa Summit in 1985 and then at the Reykjavik Summit. Paradoxically, Reagan was both driving the popular uprising against hard-line policies and pursuing and embracing the anti-nuclear weapons agenda. Gorbachev and Reagan held a meeting at the Reykjavik summit to de-nuclear the world. Both leaders agreed on the complete removal of the weapons, but the deal failed due to Reagan's SDI program [6].

\section{Conclusion}

When Gorbachev took office in 1985, he was aware that the Soviets had to undergo a radical revision. The 1980s saw Gorbachev and Reagan meet many times. Although a positive result was not obtained at first in these negotiations, it was decided with the INF agreement signed in 1987 to remove and destroy medium-range missiles in Europe. In principle, it was agreed on the reduction in strategic weapons [2].

According to Reagan; the national space policy of the USA consists of components such as increasing the security of the USA, maintaining the leadership of the country in the field of space, encouraging the private sector to civil space applications, investigating distant national interests and cooperating with other countries in the free use of space. A little differently, the Soviets were aiming to dominate space, not to exist in space. In fact, this was generally in line with the Soviet military strategy. The Soviets always preferred to dominate rather than exist. The war for domination, which was once waged between the USA and Britain in the seas, continued in space between the USA and the Soviets during the Cold War $[3]$.

The USA's Star Wars project and its rapid arms race brought the Soviets to the brink of economic and financial collapse. When Mikail Gorbachev came to power in 1985, he sought reforms for democratization and decided to end the arms race. Gorbachev expressed that he honestly wanted to improve relations with the West and was ready to negotiate with the United States. On December 8, 1987, Intermediate-Range Nuclear Forces Treaty (INF) was 
signed between the US and the Soviets. This agreement envisioned the destruction of all nuclear and conventional (non-atomic) ground-launched missiles with a range of 500 to 5500 $\mathrm{km}$, including the famous SS-20s and Pershing II's, within three years. This agreement was the first in terms of nuclear disarmament and meant the end of the arms race between the two superpowers [2].

This strategy, in which Reagan abandoned his softening policy and sought nuclear supremacy, left its mark on the 1980s, like the "preventative war doctrine" put forward by the President Bush. The common aspects of these two policies are that the United States is ready for a limited nuclear war, is ready for war in Europe and many other parts of the world, and has superiority in the seas. As mentioned above, Reagan speeded strategic nuclear modernization strategies and propelled modern exertions to form a nationalized missile defense system via a Strategic Defense Initiative (SDI), fostering conflicts with the Soviet Union and provoking extensive public distress on the probability of war amid globe's two foremost nuclear superpowers.

Reagan and his counterparty Gorbachev ultimately settled the milestone IntermediateRange Nuclear Forces (INF) treaty and founded the basis for the Strategic Arms Reduction Treaty (START), that was completed in 1991 [4]. Nonetheless, the complete assurance of Reagan's and Gorbachev's propositions for far-reaching nuclear weapon reductions stay unsatisfied. American and Russian nuclear strengths, though reduced, still mutually challenge, and various strategic weapons systems fostered by Reagan still endure or have been restored or modernized with today's technology.

\section{References}

1. S. Glasstone, W. H. Jordan, Nuclear Power and Its Environmental Effects (American Nuclear Society, NY,1980)

2. M. Anderson, A. Anderson, Reagan's Secret War: The Untold Story Of His Fight To Save The World From Nuclear Disaster (Three Rivers Press, CA, 2010) https://doi.org/10.1162/jcws_r_00055

3. S. Schwartz, Atomic Audit: the Cost and Consequences of U.S. Nuclear Weapons Since 1940 (Brookings Institution Press, Washington, 1998)

4. R.E. Powaski, Return to Armageddon: The United States and the Nuclear Arms Race 1981-1999 (Oxford University Press, NY, 2000) https://doi.org/10.1086/ahr/106.5.1837

5. G.P. Shultz, Turmoil and Triumph: My Years as Secretary of State (Charles Scribner's Sons, NY, 1993) https://doi.org/10.1086/ahr/98.4.1203

6. S.W. Hook, J. Spanier, Democracy and Security 12(4), 333-337 (2016) https://doi.org/10.1080/17419166.2016.1236635

7. H.M. Kristensen, R.S. Norris, Bulletin of the Atomic Scientists January/February (2014) http://bos.sagepub.com/content/70/1/85.full.pdf+html 